\title{
THE CASE FOR CORPORATE RESPONSIBILITY: AN EXPLORATORY STUDY
}

\author{
LUCY DA PIEDADE \\ ADÈLE THOMAS \\ adelet@uj.ac.za \\ Department of Human Resource Management \\ University of Johannesburg
}

\begin{abstract}
Stakeholder demands and the introduction of the 'triple bottom line' as a means of reporting corporate performance, make it critical that South African companies assess why they should undertake corporate responsibility initiatives. This exploratory study (part two of a two-part study) investigated the issues that are being or should be addressed by companies under the banner of corporate responsibility and the reasons for this.

The views of a convenience snowball sample of consultants, academics and practitioners of corporate responsibility, was gained by means of a Delphi technique. Content analysis was employed to categorise the views into themes. The findings indicate the need for corporate responsibility action in the areas of ecology, the environment, health and well-being, building human capital and in the encouragement of economic development. Cost benefit and defensive arguments dominate the case for corporate responsibility. There is little indication that organisations have identified the opportunity of corporate responsibility initiatives to increase innovation and organisational learning and its contribution to risk management. Recommendations are made regarding the assessment of investment in this area.
\end{abstract}

Key words

Corporate responsibilty, issues, exploratory study

Corporate responsibility is often regarded as a response to the imbalances resulting from the acceleration of the globalisation process and the underdeveloped international governance systems on environmental and social issues when compared to those for economic governance (Swift \& Zadek, 2002; Zadek, 2004).

The decision to include corporate responsibility criteria as part of organisational strategy has largely been the result of discretionary corporate initiatives based on philanthropic or paternalistic attitudes (Sarre, Doig \& Fiedler, 2001). Matten and Crane (2005) highlight the confusion in terminology that includes terms such as 'corporate citizenship', 'corporate social responsibility', 'corporate social responsiveness', and the corresponding underlying philosophies and practice foci of such concepts.

More recently, a growing convergence between corporate governance and corporate responsibility issues can be observed. In the past, the two fields of study converged on issues such as board diversity, director independence and executive compensation. Now corporate governance advocates and codes increasingly refer to a number of corporate responsibility issues as falling within the fiduciary responsibility of boards and directors and being imperative to good risk management practices. Recognition has also been given to the fact that without proper governance and management accountability, corporate responsibility will not be able to be effectively institutionalised within organisations (Business for Social Responsibility, 2002).

Changes in the organisational environment appear to be forcing organisations to approach corporate responsibility more scientifically, requiring them to effect and measure initiatives as dictated by recent regulation in this area, for example by the Code of the King Committee on Corporate Governance (Institute of Directors, 2002). These changes include: a growing media focus on corporate practices, an increase in voluntary codes (such as the Global Compact, ISO 14001, the Global Reporting Initiative and the AA1000 series), tightening of legislation, a more socially-engaged and better educated population with higher expectations around corporate conduct, increased willingness of investors to invest in companies that promote socially responsible practices and increased activism from non-governmental organisations (McKinsey \& Company,
2002; Paine, Deshpande, Margolis \& Bettcher, 2005; Visser, 2005; Vogl, 2003). Increasingly, organisations are being obliged by regulation to produce codes of ethics and to report on their social and environmental as well as financial performance (Paine et al., 2005). For instance, the Sarbanes-Oxley Act (2002) requires US companies to disclose whether they have a code of ethics in place. Some jurisdictions now legislate for the disclosure of social and environmental performance in financial statements and it appears that more governments are considering legislation in this regard (Vogl, 2003). Indices for corporate responsibility, such as the FTSE4Good and the Dow Jones Sustainability World Index, now allow socially responsible investors to invest in companies with good citizenship records (European Commission, 2003; Vogl, 2003). In South Africa, companies listed on the JSE Securities Exchange are obliged to report on their activities in the economic, social and environmental arenas. In this regard, company adherence to the recommendations furnished by the King Report on Corporate Governance (Institute of Directors, 2002) have been made admission requirements for listed companies.

There are currently a myriad of corporate responsibility initiatives across the world and almost as many codes of good conduct that have been devised by various international organisations. The most prominent of these are: The United Nations Global Compact; the International Labour Organisation Conventions; the OECD Guidelines for Multinational Enterprises, the International Standards Organisation 14000 Series, Accountability 1000, the Global Reporting Initiative, The Global Sullivan Principles and Social Accountability 8000 (Ethical Corporation, 2003). Most corporate responsibility advocates are calling for a rationalisation of these initiatives and more guidance for organisations on which standards to adopt (Locke, http://mitsloan.mit.edu/50th/corpcitizenship). The danger currently exists that corporate responsibility will become merely another reporting requirement and will not be integrated into corporate strategy (Paine et al., 2005; Straughan, 2003).

Grayson and Hodges (2001) point to the interaction of four forces or signposts that make corporate responsibility a mainstream business issue, namely: 1) the development of technology and communications which result in companies 'having no place to hide', 2) the increased prominence of multinationals globally and the growth in the value and visibility of their brands which make them more susceptible to 
scrutiny; 3) demographic change and development which encompasses issues such as an ageing population in the developed world, skewed income distribution, limited access to health, education and jobs; and 4) the revolution of values and the decline in deference for institutions.

Zadek (2001; 2004) has identified four broad, interrelated categories that may be adopted by organisations in the name of the 'business case' for corporate responsibility. He notes that these exist on a continuum from the defensive case through the traditional or cost-benefit case and the strategic case to the new economy business case. The organisation is reactive in the first two cases, ensuring legal compliance or adherence to basic stakeholder requirements only. With regard to the strategic business case, corporate responsibility becomes an integral strategic component of long-term organisational performance. The new economy business case or civil stage involves learning, innovation and risk management of acquiring and acting on stakeholder information in a way that builds new competencies or products in the organisation, and provides innovative ideas about how to manage risk and increase profits (Waddock \& Smith, 2000; Zadek, 2001; 2004). In this regard De Jongh (2004) notes the challenges of managing social risk, such as HIV/AIDS in South Africa.

Most scholars agree that there is no universally accepted definition of corporate responsibility or a definitive framework of how it should be applied (Carroll, 1979; Clarkson, 1995; Grayson, 2005; Matten \& Crane, 2005; Mirvis \& Googins, 2004; Wood, 1991) and according to Carroll and Buchholtz (2000) the responsibility of organisations entails the simultaneous fulfilment of the organisation's economic, legal, ethical and philanthropic responsibilities. In the context of this study corporate responsibility is defined as the commitment of organisations to act in the interest of both business and sustainable economic development based upon ethical values, compliance with legal requirements, and respect for and engagement with people, communities and the environment.

\section{Elements of a corporate responsibility strategy}

An ever-increasing number of issues are being incorporated in the concept of corporate responsibility making it difficult for organisations to prioritise action in this area. Grayson and Hodges (2001) point to the growing importance of doing business in emerging economies and to the growing need for transnational organisations in these regions to demonstrate the added value of their presence and maintain high corporate responsibility standards regardless of less stringent local legislation. The authors point to ways in which value can be demonstrated in these economies by addressing stakeholder expectations and needs which often tend to be very different from responsibility issues in developed economies. Examples include building human capital by investing in education and transferring skills, encouraging good governance, assisting social cohesion, strengthening economies, protecting the environment, and addressing health-related matters, in particular HIV/AIDS, issues noted also by Vermier, Van de Velde and Corten (2005). Speaking of South Africa, White (2004, p.21) states that "(i)ssues unknown and/or unspoken only a decade ago now regularly appear on the corporate agenda, either by choice of corporations themselves or through initiatives of governments, activists and, increasingly, investors. Human rights, HIV/AIDS, drug pricing, climate change, outsourcing, sweatshops - these and many others are moving to centre stage ... and are challenging business in ways unthinkable even five years ago".

Social responsibility is increasingly being seen as a necessity for doing business in developing economies that lack the infrastructure and capacity to build social capital. Investment in local communities is seen to be a prerequisite in contributing to a sustainable, healthy and stable business environment in which investments will be protected and produce returns (World Business Council for Sustainable Development, 2003). In this regard,
Hamann (2003, p.239) notes that "(t)o embrace economic, social and environmental aspects of sustainability in a holistic manner, and to provide maximum development benefits, corporate social responsibility must be integrated into the core activities and decision making of a company. Hence, sustainability needs to be seen as a key concern by top management".

Issues critical to economic development, sustainability and stability in the South African context, include: poverty alleviation, addressing of health issues such as HIV/AIDS, improving education, controlling industrial pollution, promoting environmental conservation, preventing resource depletion, addressing land redistribution, improving governance and government capacity to manage development processes, housing and access to credit (African Institute for Corporate Citizenship, undated; de Jongh, 2004; Visser, Middleton and McIntosh, 2005). These issues have traditionally not been considered to be the responsibility of business. However many companies are attempting to address these issues and that of poverty generally and not necessarily from a philanthropic perspective but because they believe it benefits their organisations (Forstater, 2002). Hamann (2003) believes that social responsibility initiatives in South Africa necessarily must go beyond philanthropic investment to embrace developmental initiatives due to the country's history of apartheid and concomitant lack of previous state support for social development and Hamann and Acutt (2003, p.255) note that, in the South African context, social responsibility "is meant to link the market economy to sustainable development".

The broad conclusion drawn at the 2002 World Summit on Sustainable Development was that "greater involvement from the business community is the key to sustainable development and issues such as biodiversity and climate change, health and in particular the challenges regarding HIV/AIDS, water and sanitation, education, and economic development are either intrinsic to or inseparable from that overarching goal" (Blyth, 2002, p. 26).

A survey conducted by Environics International (2002) in 25 developed and developing countries sought to highlight which of the following five categories respondents believed business was able to make the most impact: cleaning up the environment, improving education, reducing poverty and homelessness, improving healthcare and addressing crime. Respondents in developing countries, including South Africa, indicated that they believed that corporations could make their greatest contribution to society in the area of reducing poverty and homelessness and improving education. This was in contrast to the participants from developed countries who mostly voted for more action in the area of protecting the environment. Post (2002) and Visser and Sunter (2002) note how, in South Africa, the focus of corporate responsibility has shifted from that, primarily, of environmental responsibility to the incorporation of issues such as health and safety as well as social and economic issues.

\section{Rationale for the study}

The present exploratory study investigates the elements of corporate responsibility strategy in South Africa and the justification for that strategy with a view to making recommendations to South African organisations. The study seeks to understand, in descriptive terms, what elements are included in corporate responsibility strategy. While that which organisations are doing and that which they should be doing may be completely different, the study aims to integrate the descriptive findings with a normative interpretation of what organisations should be doing by considering the findings together with the major challenges for corporate responsibility in South Africa identified in the literature, in this way reflecting the 'contrasting/combining' approaches discussed by Donaldson and Preston (1995).

The study is significant now in view of increased opposition to business influence in various areas of policy development. Critics 
of the corporate responsibility or citizenship movement believe that it is a public relations exercise devised by organisations to appease growing dissatisfaction with the increasing transnational reach of multinational companies and their subversion of the ability of governments to make and enforce development policies (Vogl, 2003). Still others have pointed to the fact that lack of consensus for management, measurement and verification of corporate responsibility contributes to the perception that these initiatives in organisations are merely window dressing (Ethical Corporation, 2002).

There is a growing body of evidence however, that suggests that organisations can be socially responsible as well as profitable and that a lack of responsiveness to gross imbalances in access to basic amenities and opportunities results in an unsustainable business environment (Amalric \& Hauser, 2005; Aqueveque, 2005; Chiang \& Chia, 2005; Ethical Corporation, 2002; Hall \& Vredenburg, 2005; Klein, Smith \& John, 2004; McKinsey \& Company, 2002; Orlitsky, 2005; Vermeir et al., 2005).

It has also become clear that the value of intangible assets in organisations today is growing. According to MacMillan and Joshi (1997), chief executive officers regard reputation as the most valuable intangible asset, a finding supported by Dowling (2004), Mirvis and Googins (2004) and Werther and Chandler (2004). Organisational success now depends as much on production facilities and capital as it does on relationships with suppliers, the management of brands, the quality of business processes, the retention of talented employees and a corporate culture that is conducive to success in a particular industry (Ethical Corporation, 2002; Grayson, 2005; Roberts, Keeble \& Brown, 2002).

\section{AIM OF THE STUDY}

The objective of this study was to shed light on which corporate responsibility issues South African corporations should be focusing upon and why they consider these to be important to their corporate strategy.

The study seeks answers to the following questions:

1. Which issues should be addressed by a corporate responsibility strategy in the South African context?

2. Which factors constitute the business case for corporate responsibility in South African organisations?

\section{The following propositions are posited:}

Proposition No 1:

South African companies do not incorporate into their corporate responsibility strategies, issues that are critical to sustainable business such as HIV/AIDS, economic development and education (de Jongh, 2004; Hamann, 2003; Hamann and Acutt, 2003; Visser, Middleton and McIntosh, 2005, Visser, 2005).

Proposition No 2:

South African companies base their case for corporate responsibility mainly on defensive or cost-benefit arguments (Zadek 2001; 2004).

Proposition No 3:

South African companies develop corporate responsibility strategies in order to promote innovation and learning and risk management (de Jongh, 2004; Waddock \& Smith, 2000; Zadek, 2001; 2004).

\section{RESEARCH DESIGN}

\section{Research approach}

Data were collected from consultants, academics and practitioners of corporate responsibility and sustainability by means of a Delphi technique. Information gathered in this way was subjected to qualitative content analysis. The study dealt with poorly defined concepts and a highly uncertain environment where the past has very little bearing on the understanding of these concepts in the future. Expert opinion that documents both facts and opinion (Rowe \& Wright, 1999) was used to capture a wide range of interrelated variables common to complex research problems. Anonymity makes panellists more inclined to revise their views if necessary (Tersine \& Riggs, 1976). This method is also useful when experts are geographically dispersed (Story, Hurdley, Smith \& Saker, 2001). Moreover, it is relatively inexpensive to organise and allows for the participation of larger groups than can normally be brought together for a meeting (Williams \& Webb, 1994).

\section{Research methodology}

Participants/respondents

The research population comprised all academics, consultants and practitioners who are involved in the study or field of governance, ethical business practices and corporate responsibility in South Africa and who are able to express expert opinion on these issues. Snowball sampling was applied in order to include recommended specialists on the panel. The principal selection criteria were expertise and diversity. Factors such as location, gender, social and political orientation were considered in the selection of experts in order to ensure sufficient diversity of response and in order to minimise the subjective bias of response prevalent in this method. Experts chosen were not necessarily equally qualified in the same areas, but were qualified in subparts of the research question. According to Linstone and Turoff (1975) there are no experts on policy issues but merely informed advocates and referees and their opinions contribute to a deeper understanding of the issue but do not necessarily result in resolution of the policy question. The panel was selected on an access/availability basis and, as such, a convenience sample was used (Linstone \& Turoff, 1975). Expertise was adjudicated by the researchers based on years of experience in the fields of governance, ethics and corporate responsibility as well as on published works and referrals from organisations active in the field and in academia.

The objective was to retain at least fifteen panellists in the final round of the study, based on the recommendations of Story et al. (2001) who note that participation rates typically reduce by between a third and one-half after each round of the study. As a result, 30 panellists were targeted to constitute the panel. A total of eighteen panellists participated in the first round of the study. Twelve of these proceeded to complete the second round of the study.

Table 1 profiles the panellists and provides an indication of who participated in each round of the study.

\section{Method of data collection}

The Delphi method involves a number of rounds of data collection. The first round is unstructured to allow individual experts relative freedom to identify and elaborate on the pertinent issues from their point of view (Story et al., 2001). Issues are then consolidated by the researcher and re-sent to the panellists for further comment and discussion. The number of rounds seldom goes beyond one or two iterations (Rowe \& Wright, 1999).

Although Delphi was originally devised as a forecasting tool where parameters of estimation are largely unknown, it is also used for the analysis of social or policy issues. The Policy Delphi is based on the premise that the decision-maker is not interested in reaching consensus on a particular issue, but rather, to have an informed group present all the options and supporting evidence for his consideration (Linstone \& Turoff, 1975). As a result, the study aims to obtain a clear definition of the various standpoints taken by panelists and identify the main arguments for those positions (Story et al. 2001). 
TABLE 1

Profile of Respondents

\begin{tabular}{|c|c|c|c|c|}
\hline Respondent & Industry/Sector & Position & $\begin{array}{c}\text { Round } \\
1\end{array}$ & $\begin{array}{l}\text { Round } \\
\quad 2\end{array}$ \\
\hline 1 & NGO & $\begin{array}{l}\text { Corporate Citizenship } \\
\text { Manager }\end{array}$ & $\mathrm{Y}$ & $\mathrm{N}$ \\
\hline 2 & $\begin{array}{l}\text { Development } \\
\text { Finance }\end{array}$ & Social Impact Specialist & $\mathrm{Y}$ & Y \\
\hline 3 & International NGO & Facilitator & Y & Y \\
\hline 4 & Law & Associate & Y & $\mathrm{N}$ \\
\hline 5 & Retail & Corporate Affairs Manager & Y & Y \\
\hline 6 & Consultancy & Director & Y & Y \\
\hline 7 & Automotive & Corporate Affairs Manager & Y & $\mathrm{N}$ \\
\hline 8 & SME NGO & Director & Y & $\mathrm{Y}$ \\
\hline 9 & Audit/Consulting & Partner & Y & $\mathrm{N}$ \\
\hline 10 & Academia & Director & Y & Y \\
\hline 11 & Mining NGO & Advisor & Y & Y \\
\hline 12 & Banking & CSR Manager & Y & $\mathrm{N}$ \\
\hline 13 & Mining & CSR Manager & Y & $\mathrm{N}$ \\
\hline 14 & Pharmaceuticals & Corporate Affairs Manager & Y & $\mathrm{Y}$ \\
\hline 15 & $\begin{array}{l}\text { Ethical business } \\
\text { benchmarking } \\
\text { NGO/consultancy }\end{array}$ & Director & Y & $\mathrm{Y}$ \\
\hline 16 & $\begin{array}{l}\text { Beverage } \\
\text { Production/ } \\
\text { Distribution }\end{array}$ & Group Social Officer & $\mathrm{Y}$ & $\mathrm{Y}$ \\
\hline 17 & NGO & Director & Y & Y \\
\hline 18 & $\begin{array}{l}\text { Sustainability } \\
\text { Consultancy }\end{array}$ & Managing Director & Y & $\mathrm{Y}$ \\
\hline
\end{tabular}

Legend

$\mathrm{Y}=$ participated

$\mathrm{N}=$ did not participate

Procedure

The study was performed in two iterations:

\section{Round 1}

In the first round the 30 panellists who agreed to participate in the study were presented with an unstructured questionnaire containing open-ended questions based on the research questions posed above:

1. What issues are being addressed or do you believe should be addressed in a corporate responsibility strategy in South Africa?

2. What constitutes the business case for action in this area?

Panellists were asked to return their answers via email and were encouraged to identify additional issues that they believed should be included in the next round of the study as recommended by Story et al. (2001). Eighteen responses were received in this round, representing a response rate of 60 percent. Responses from Round 1 were summarised and grouped into 12 nominal themes using content analysis and were sent to the panellists for consideration and comment in Round 2.

\section{Round 2}

Panelists who participated in Round 1 were requested to study the two tables that contained the summaries of the responses in Round 1 and to indicate their agreement or disagreement with the results, re-evaluate their choices, provide reasons to support their opinions and to make any additional comments or add any additional factors or issues. Twelve panellists responded in Round 2 of the study and all responses were usable. The objective of this study was not to obtain consensus on a determining factor or to rank factors in order of importance but to elucidate ideas pertaining to the research problem, and ranking of responses or determining the statistical variance in responses was not considered to be appropriate.

Originally it was planned to conduct three rounds of the Delphi study. However, it was decided to terminate the research process after Round 2 for the following reasons:

1. After the second round of the research, the respondents had reached reliable consensus on the research question;

2. The issues identified by the panellists related closely to those that had been obtained from the literature;
3. The panellists did not make any changes or additions to the issues that had been identified in Round 2 of the study.

Analysis of data

The data collected from Rounds 1 and 2 of the study were analysed using a content analysis technique whereby many words of text are compressed into fewer content categories based on explicit rules of coding (Stemler, 2001), devised from words, phrases, sentences or themes. A thematic coding system was applied in this study. Themes and constructs regarding issues which should be or are included in a corporate responsibility strategy were identified as well as constructs as to why the application of corporate responsibility in the corporate arena was considered important and necessary in South Africa.

\section{RESULTS}

The results of Round 1 are presented in two tables. The first table (Table 2) lists the issues identified by the panellists that do or should form part of a corporate responsibility strategy in South Africa, classified into categories. The frequency of the category issues listed by the panellists is also shown.

TABLE 2

CORPORATE RESPONSIBILITY ISSUES IDENTIFIED IN ROUND 1

\begin{tabular}{lll}
\hline Theme & Statement & Frequency $\%$ \\
\hline $\begin{array}{l}\text { Ecology \& } \\
\text { environment }\end{array}$ & $\begin{array}{l}\text { Biodiversity, emissions \& pollution, } \\
\text { waste management, environmental } \\
\text { issues generally }\end{array}$ & \\
& Total for category
\end{tabular}

Health \&

well-being

Total for category

$10,8 \%$

of alDS (awareness and provision well-being and quality of life issues, health issues generally

Total for category

Diversity \& human rights

Employment equity, human rights

Total for category

$65 \%$

Communities Community development in business vicinity or making company skills available, community development generally (donations and other) Total for category

$5,8 \%$

Education,

training and

skills

Education \& training (within field of

interest to company), leadership/

management skills development/

mentoring, skills and human capital

development (generally), education

infrastructure and management,

development of entrepreneurship skills)

Total for category

Transformation Black economic empowerment, land

distribution, preferential procurement/ market access

Total for category

13

$10,8 \%$

Infrastructure

Housing, schools, clinics, roads etc. Total for category

Transparency/ Supply chain compliance (ensuring reporting/

compliance \& acceptable standards), responsible practices in promoting and selling measurement products, accountability processes \& corporate transparency on non-financial issues (sustainability reporting), reporting on stakeholder engagement, embedding corporate responsibility practices (reporting and other)

Total for category

Governance

Governance practices monitoring and structures

Total for category

Economic development/ Job creation

(particularly SMEs) and job creation, crime prevention, promotion of tourism, service delivery and capacity building, engagement on poverty reduction as opportunity or risk, access to finance Total for category 
Regionalism

Nepad \& African development, promotion of human rights in African countries

Employee/labour relations, stakeholder engagement

Total for category

Total scores
Total for category
Labour/stakeholder relations
TABLE 3

BusinesS CASE RATIONALE IDENTIFIED IN RoUND 1

\begin{tabular}{|c|c|c|c|}
\hline Theme & Statement & Frequency & $\%$ \\
\hline Cost-benefit & $\begin{array}{l}\text { Obtain/maintain licence to operate, } \\
\text { attract/retain business partners \& } \\
\text { investors, gain access to capital, } \\
\text { mandated by legislation, recruit and } \\
\text { retain quality employees, labour } \\
\text { productivity, labour stability, } \\
\text { participate in state tenders \& } \\
\text { contracts, cost reduction } \\
\text { Total for category }\end{array}$ & 28 & $49 \%$ \\
\hline Defensive & $\begin{array}{l}\text { Reputation \& brand equity, maintain } \\
\text { competitiveness, in order to participate } \\
\text { in Social Responsibility Index, to } \\
\text { maintain a stable economic and social } \\
\text { environment, improve relationship } \\
\text { with stakeholders/build goodwill } \\
\text { Total for category }\end{array}$ & te & $26 \%$ \\
\hline Strategic & $\begin{array}{l}\text { New market/product opportunities } \\
\text { Sustainable development } \\
\text { Total for category }\end{array}$ & 10 & $18 \%$ \\
\hline \multirow[t]{3}{*}{$\begin{array}{l}\text { Learning, } \\
\text { Innovation \& } \\
\text { Risk Management } \\
\text { (New Economy } \\
\text { business case) }\end{array}$} & Risk management & & \\
\hline & Total for category & 4 & $7 \%$ \\
\hline & Total scores & 57 & $100 \%$ \\
\hline
\end{tabular}

No additional business case arguments were added during Round 2. Certain constructs were however eliminated as a result of the feedback of the majority of the panellists who felt that they were irrelevant to the research question, as noted above.

The changes arising from Round 2 are depicted in Table 4 .

TABLE 4

CORPORATE RESPONSIBILITY ISSUES IDENTIFIED IN ROUND 2

Regionalism also emerged as an issue, although this was considered to be irrelevant by the majority of the respondents in Round 2.

Consideration of labour and stakeholder relations was also identified by some of the respondents as a necessary element of corporate responsibility.

Table 3 lists the business case arguments for a corporate responsibility strategy, classified into four categories, based on the literature on this topic. Frequencies with which the various business case arguments were mentioned are also indicated.

While the researchers had to make judgments in the classification process, those items categorised as 'cost-benefit' were seen as being part of the most reactive strategy with basic tangible, immediate and measurable outcomes for organisations as noted by Zadek $(2001 ; 2004)$. It can be argued that the items categorised as 'defensive', while also being part of a reactive strategy as articulated by Zadek $(2001 ; 2004)$, tend towards greater 'future orientation' with less immediate payoff and bottom-line benefit to the organisation.

In Round 2 the panellists indicated their agreement or disagreement with the issues listed in Round 1 and were presented with the opportunity to include additional issues. Content analysis was used to distil the responses and the responses were evaluated with a view to establishing whether there was reliable consensus that 1 ) the issues listed were those that companies should address in their corporate responsibility strategy and 2) the arguments raised constituted the case for corporate responsibility in the opinion of the panel.

\begin{tabular}{|c|c|c|c|}
\hline Theme & Statement & Frequency & $\%$ \\
\hline $\begin{array}{l}\text { Ecology \& } \\
\text { environment }\end{array}$ & $\begin{array}{l}\text { Biodiversity, emissions \& pollution, } \\
\text { waste management, environmental } \\
\text { issues generally } \\
\text { Total for category }\end{array}$ & 13 & $11,5 \%$ \\
\hline $\begin{array}{l}\text { Health \& } \\
\text { vell-being }\end{array}$ & $\begin{array}{l}\text { HIV/AIDS (awareness and provision of } \\
\text { anti-retrovirals), safety, employee } \\
\text { well-being and quality of life issues, } \\
\text { health issues generally } \\
\text { Total for category }\end{array}$ & 22 & $19,47 \%$ \\
\hline iversity \& & Employment equity, human rights & & \\
\hline & Total for category & 6 & $5,3 \%$ \\
\hline Communities & $\begin{array}{l}\text { Community development in business } \\
\text { vicinity or making company skills } \\
\text { available, community development } \\
\text { generally (donations and other) } \\
\text { Total for category }\end{array}$ & 7 & $6,1 \%$ \\
\hline $\begin{array}{l}\text { Education, } \\
\text { training and } \\
\text { skills } \\
\text { development }\end{array}$ & $\begin{array}{l}\text { Education \& training (within field of } \\
\text { interest to company), leadership/ } \\
\text { management skills development/ } \\
\text { mentoring, skills and human capital } \\
\text { development (generally), education } \\
\text { infrastructure and management, } \\
\text { development of entrepreneurship skills } \\
\text { Total for category }\end{array}$ & $s$ & $17,7 \%$ \\
\hline Transformation & $\begin{array}{l}\text { Black economic empowerment, } \\
\text { preferential procurement/market access } \\
\text { Total for category }\end{array}$ & 12 & $10,6 \%$ \\
\hline Infrastructure & $\begin{array}{l}\text { Schools, clinics, roads etc. } \\
\text { Total for category }\end{array}$ & 1 & $0,8 \%$ \\
\hline
\end{tabular}


Transparency/ Supply chain compliance (ensuring reporting/ acceptable standards of governance and compliance \& CSR in supply chain), responsible measurement practices in promoting and selling products, accountability processes \& corporate transparency on non-financial issues (sustainability reporting), reporting on stakeholder engagement, embedding corporate responsibility practices (reporting and other) Total for category

Governance

Governance practices monitoring and structures

Total for category

Economic development/ Job creation

Enterprise development (particularly SMEs) and job creation, service delivery and capacity building in government, engagement on poverty reduction as opportunity or riskAccess to finance/ community banking

Total for category

Labour/ stakeholder relations

Employee/labour relations, stakeholder engagement

\begin{tabular}{lcc} 
Total for category & 7 & $6,2 \%$ \\
Total scores & 113 & $100 \%$ \\
\hline
\end{tabular}

\section{DISCUSSION}

Proposition 1 posited that:

South African companies do not incorporate into their corporate responsibility strategies, issues that are critical to sustainable business such as HIV/AIDS, economic development and education.

This proposition is not supported by the findings. As indicated in Table 4, the following issues constituted ten percent or more of the total responses: health and well-being (19.5\%), education, training and skills development (17.7\%), and ecology and the environment (11.5\%). Economic development/job creation, however, only constituted $8.8 \%$ of the total responses. Transformation (primarily economic in nature) constituted 10.6 percent of responses.

Almost twenty percent of the respondents cited issues of health and well-being as being essential to consider, with the majority of these responses indicating that HIV/AIDS, as it pertains to creating awareness around the issues and the provision of antiretroviral drugs, was an issue that must be addressed in a corporate responsibility strategy in South Africa. The issues of HIV/AIDS, education and investment in human capital and environmental issues were all highlighted in the literature as issues where the business community has a responsibility in the interests of creating and maintaining a stable and productive business environment (African Institute of Corporate Citizenship (undated); Blyth, 2002; de Jongh, 2004; Forstater, 2002; Hamann, 2003; Hamann \& Acutt 2003; Visser, Middleton and McIntosh, 2005; World Business Council for Sustainable Development, 2000). Given that over forty two million people worldwide are living with HIV/AIDS (Petkoski \& Kersemaekers, 2003), the impact on business and economic development is easy to discern. Research conducted under the auspices of the World Bank Institute and the United Nations Global Compact (Petkoski \& Kersemaekers, 2003) indicates that in countries with a high prevalence of HIV, companies are increasingly becoming important players in providing education, initiating awareness campaigns and intervention strategies. The business case, in cost-benefit or defensive terms, for corporate intervention in the face of such a crisis is self evident and more readily measured in terms of return on investment. Organisations operating in these environments are facing more pressure than ever to disclose information on their HIV/AIDS initiatives since the issue has become relevant for the risk analysis of investors.
Economic development, predicted in the literature (Blyth, 2002; Hamann, 2003; Hamann \& Acutt 2003; Grayson \& Hodges, 2001; Vermier et al., 2005; Visser, Middleton and McIntosh, 2005), did not emerge as strongly from the findings as expected. Economic development was mentioned by just under ten percent of the respondents as an essential factor to be included. Some of the panellists expressed surprise in Round 2 that the issue of economic development had not featured more prominently in the participants' responses and re-emphasised the importance of this issue in the comments during Round 2.

The category 'transformation' refers essentially to economic transformation and together with the category 'infrastructure' these categories might also reasonably be considered to reside under 'economic development'.

Education, training and skills development emerged as an important corporate responsibility theme identified by approximately 18 percent of the respondents. Both Blyth (2002) and Grayson and Hodges (2001) discuss the responsibility of organisations to create jobs and encourage economic development at length. By creating jobs and generating export revenues and taxes, expanding local infrastructure, transferring technology and international standards, and supporting local business development, organisations can demonstrate added value in emerging economies (Grayson \& Hodges, 2001).

A theme that unexpectedly arose was that of transparency, reporting and measurement. The researchers had deemed these issues to be aspects of implementation of corporate responsibility strategy rather than a social or economic issue in itself. The fact that these issues were identified and represented over ten percent of the responses points to the growing importance of implementation and embedding of corporate responsibility in organisations and the extent to which this was being emphasised in the corporate responsibility debate. The inclusion of both these categories under economic development elevates the importance of the issue as predicted.

The constructs that emerged from the findings centred around enterprise development and job creation, access to finance and the responsibility of organisations to address the issue of poverty reduction generally. The results were not surprising in the South African context given the high unemployment rates and the recent prominence of the issue of access to finance and the responsibility of the financial sector in this area.

The findings confirm Grayson and Hodges' (2001) assertion that organisations should be led by the cultural and societal norms of a country in determining the extent of their corporate responsibilities. Stigson (2003) confirms that the expectations of an organisation's responsibility for addressing a particular issue are likely to vary between different stakeholders depending on their country and culture. To this consideration can be added the argument advanced by Donaldson and Preston (1995) indicating that the theoretical approach adopted by organisations when dealing with a concept, whether descriptive (in this case, describing or explaining organisational practices), normative (in this case, identification of practice guidelines), or instrumental (identifying connections) will determine how an organisation approaches the issue, for example its strategy of corporate responsibility. Setting the boundaries of the role and responsibility of an organisation is therefore often a question of internal and external dialogue and negotiation.

Another factor in the boundary-setting process is the recognition that governments cannot address social challenges such as poverty and corruption, alone. In emerging markets where the institutional frameworks are weak, companies have to promote their own values and ethical systems and ensure that these meet responsibility requirements (Grayson \& Hodges, 2001; Stigson, 2003). 
The findings indicate that South African organisations are attempting to define what the responsibility of business is in the country given the social and economic issues that exist and how this responsibility can be balanced with their own corporate priorities.

Proposition 2 stated:

South African companies base their case for corporate responsibility mainly on defensive or cost-benefit arguments.

This proposition is supported by the findings with almost half of the responses (49\%) pointing to cost-benefit arguments for having and implementing corporate responsibility strategies and 26 percent of the responses indicating that organisations undertake corporate responsibility initiatives for defensive reasons, in line with the findings of Petersen (2005). Costbenefit factors that were mentioned by the participants include obtaining and maintaining a license to operate, attracting and retaining partners and investors, gaining access to capital, fulfilling legislative requirements and recruiting and retaining employees. Twenty six percent of the respondents believed that the business case for corporate responsibility is based on defensive arguments such as protecting reputation and brand equity and improving and maintaining relationships with key stakeholders, a finding reported by Grayson and Hodges (2001) and Zadek (2004).

Reputation management and enhancing the relationship of an organisation with its stakeholders is one of the key motivators for responsible conduct. A Market \& Opinion Research International study (2002) indicated that in 1998, 28 percent of British consumers believed that their purchasing decisions were influenced by the level of corporate responsibility demonstrated by companies. By 2002 this had risen to 44 percent of consumers. Similarly, a study by Business in the Community (2003) found that 86 percent of consumers have a more positive impression of an organisation if it is seen to be contributing towards making the world a better place. Research published by the Global CSR Monitor in 2001 (Business in the Community, 2001), showed that organisational responsibility to social, environmental and labour practices were perceived to be more important than its economic contribution in 20 countries. Similarly, a study by McKinsey and Company (2002) notes the positive relationship between investment and perceived sound corporate governance that includes social responsibility.

Faruk (2002) indicates that the overwhelming majority of senior managers in the United Kingdom (77 percent) believe that responsible business practice is 'very important' to the long-term commercial success of an organisation and issues rated as the key business drivers include protecting corporate reputation and employee recruitment and retention. The finding relating to the recruitment and retention of employees corresponds to research undertaken by Business in the Community (2003) and Zadek (2001; 2004), indicating that people wish to work for responsible organisations whose values reflect those of their own.

Engaging in responsible corporate practices is increasingly viewed as a means of facilitating access to capital. Studies by Business in the Community (2001) and McKinsey and Company (2002) confirm that investors are progressively analysing corporate social and environmental performance as part of their investment criteria and that a strong corporate responsibility record makes an organisation more attractive to investors.

Measuring the value of corporate responsibility initiatives merely in cost-benefit terms is problematic. Value is measured in a variety of ways, many of which are not immediately visible in a cost-benefit calculation (Grayson, 2005). Examples include: reputation and trust, employee morale, relationships with business partners and learning and innovation (Grayson, 2005; Grayson \& Hodges, 2001; Roberts et al., 2002).
The results of the present study also suggest that corporate responsibility initiatives are seldom undertaken unless a cost benefit or defensive imperative can be found. In the first instance it is difficult to prove that corporate responsibility and financial performance are correlated (Abbott \& Monsen, 1979; Amalric \& Hauser, 2005; Aqueveque, 2005; Aupperle, Carroll, \& Hatfield, 1985; Martin, 2002; Vogl, 2003). Second, most research on the subject indicates that companies are often forced to respond to corporate responsibility issues in order to be recognised as trustworthy business partners (Pearson, 2000), to protect their reputations (World Business Council for Sustainable Development, 2000) or because of pressure by institutional investors (Newell \& Wilson, 2002; McKinsey \& Company, 2002), communities and activists (Waddock, Bodwell \& Graves, 2002). In many of these instances no short term, positive relationship between cost and benefit exists.

The traditional cost benefit argument is also not a viable option in countries where extreme poverty exists and the social challenges are more marked (Forstater, 2002). Increasingly there is an expectation that organisations deliver shareholder value as well as societal value to a broader range of stakeholders (Freeman \& Liedtka, 1991; Freeman \& Reed, 1983; Mahon \& McGowan, 1991; Mintzberg, Simons \& Basu, 2002; Moir, 2002).

Proposition 3 posited that:

South African companies develop corporate responsibility strategies in order to promote innovation and learning and risk management.

This proposition was not unequivocally supported by the findings of the study. Although a small percentage of the respondents admitted that risk management constituted an element of the case for corporate responsibility (7\%), no mention was made by any of the respondents of opportunities for learning and innovation which corporate responsibility, through meaningful stakeholder engagement and the concomitant development of market signals, may create. This is in contrast to research that asserts that competitive advantage may be gained when using stakeholder information to build new competencies or products that ultimately increase profits (de Jongh, 2004; Grayson, 2005; Handy 2002; Hart \& Milstein, 2000; Prahalad \& Hart, 2002; Waddock \& Smith, 2000; Zadek, 2001; 2002 ; 2004). Senge (1990) notes that although shorter organisational life spans may be attributable to economic change and redistribution of resources, high corporate mortality is a symptom of the fact that most organisations learn poorly.

Corporate responsibility can be a means by which companies can better understand and manage their risk and comprehending the needs and expectations of stakeholders can be an integral aspect of risk assessments (Keeble \& Turner, 2003). Speaking of South Africa, de Jongh $((2004$, p. 29) states that there is "a fundamental 'new order of doing business' ... which ultimately requires original and unconventional strategies to develop riskcontrol measures required to manage the new order of risks".

\section{Limitations of the study}

Inherent in this exploratory study are the following limitations that impact on the generalising of the findings:

1. Panellists were selected based on nominations and referrals from organisations and institutes active in the field of corporate responsibility and business and academic contacts and were ones who indicated their willingness to participate in the research. This sample may not be representative of the population of practitioners, consultants or academics involved in the area of corporate responsibility. Similarly, the cross section of business sectors represented in the sample may not be representative of South African organisations in general;

2. Only twelve panellists completed the second round of the study which is a smaller sample than that which is recommended in the literature (Story, Hurdley et al., 2001) again impacting on the generalisation of the findings; 
3. No specific propositions about the factors identified were tested and no attempt was made to identify any causalities or dependence between the factors;

4. The research did not explore any distinguishing characteristics applicable to different industry segments;

5. The following limitations are inherent in the Delphi technique (Rowe \& Wright, 1999; Williams \& Webb; 1994): there is no recommendation regarding acceptable panel size and sampling technique and the range of panel size seems to vary arbitrarily; the follow-up response rate decreases in inverse proportion to the size of the panel which means that the validity of the result is subject to response bias; there is no rule regarding the number of iterations and some authors warn of the effects of boredom on the results of the study; the averaging process which is forced after each iteration, can also weaken the potential of group judgement; replicability of results is difficult to verify; the possibility of bias being introduced by the researchers, in the interpretation of the findings is high.

\section{CONCLUSION}

This exploratory study investigated what issues should be addressed by organisations in South Africa under the banner of corporate responsibility and the reasons for this. Although the study does not purport to establish the corporate responsibility strategies that should be addressed by every organisation in South Africa, nor the motivations for such strategies, it does shed some light on what the current thinking is in this area. The study also gives an indication of the reasons for corporate action in this area.

The results indicate that issues identified in the literature as emerging issues and ones that should concern managers in the area of corporate responsibility, were identified by the participants as those that should be incorporated in a corporate responsibility strategy in South Africa. In particular, the respondents emphasised the categories ecology and environment and health and well-being. In addition, issues that arose from the literature as being those which organisations operating in emerging markets need to pay attention to in order to demonstrate that they were adding value in their organisational environments also emanated from the findings. Specifically, the issues of building human capital and economic development appeared to be uppermost in the minds of most of the panellists.

The rationale for adopting corporate responsibility strategies and, consequently, where organisations perceive value in adopting these strategies was revealed in the study and cost benefit arguments dominate the framing of the business case. If companies in South Africa continue to assess their responsibility to society merely in cost-benefit terms they could be jeopardising the future of their organisations both in terms of a failure to consider non-financial risks to their organisations and the needs of their stakeholders and a failure to harness the opportunities that a progressive approach to corporate responsibility can produce. The notion of measuring the value of corporate responsibility practices in terms of the opportunities that they present for learning and innovation as well as effective risk management did not emerge from the findings. This is in contrast to literature that indicates that corporations that are able to acquire and act on high quality information about stakeholder interests that are likely to impact their organisations and translate into market signals, are more able to build new competencies and understand and learn how to respond to business risk (de Jongh, 2004; Zadek, 2001; 2004).

Conclusions that can be drawn from the research are: first, that organisations need to determine which issues to address in their corporate responsibility strategies based on their understanding of their relationship with the societies in which they operate, the needs of their stakeholders and the theoretical underpinnings of their understanding of corporate responsibility; and second, the way in which value of corporate responsibility initiatives is measured will need to be assessed differently since value in this area is difficult to establish in absolute short term cost benefit terms.

In its determination of what it should be doing and how it should be responding to society's expectations, the organisation must establish how its stakeholder relationships add value. Analysing the strength of its stakeholder links as the principal means through which organisations create social capital will enable the organisation to measure the value of corporate responsibility and make the appropriate case for action. Information from stakeholders can be used to create competitive advantage in the areas of risk management, innovation, creating new markets, reputation and brand value.

\section{Suggestions for further research}

The following issues should be considered in future research endeavours:

1. A more specific industry-based study could yield richer results since corporate responsibility initiatives must be formulated bearing the needs of organisational stakeholders in mind that may differ from industry to industry and even perhaps from region to region;

2. A study using a bigger and more diverse sample could more adequately be representative of South African business opinion;

3. A case study examining the successful implementation of a corporate responsibility strategy could produce useful results and benchmarks for other organisations. In the same way case studies on corporate responsibility measurement and reporting could provide practical solutions to an issue that is still very much in the developmental stage;

4. Measurement techniques identifying how to implement corporate responsibility strategies effectively and how to measure for corporate responsibility success in South Africa could advance the meaningful implementation of corporate responsibility.

Most of the existing research has not been able to establish a correlation between increased profitability and the assumption of socially responsible practices (Martin, 2002). However, as investors and stakeholders begin to pay closer attention to nonfinancial corporate performance indicators, organisations will be expected to put corporate responsibility on its strategic agenda. The consensus appears to be that the value created by effective corporate responsibility management goes beyond cost savings and increased efficiency. Corporations are beginning to understand that addressing and learning from social and environmental challenges can enhance their competitiveness.

\section{REFERENCES}

Abbott, W.F.\& Monsen, J.R. (1979). On the measurement of corporate social responsibility: self reported disclosures as a method of measuring corporate social involvement. Academy of Management Journal, 22 (3), 501-515.

African Institute of Corporate Citizenship (undated). Corporate Citizenship. http://www.aiccglobal.com/images/ CorporateCitizenship.pdf (accessed 12 December 2003)

Amalric, F. \& Hauser, J. (2005). Economic drivers of corporate responsibility activites. The Journal of Corporate Citizenship, Winter, 20, 27-38.

Aqueveque, C. (2005). Marketing and market development: Signalling corporate values - consumers' suspicious minds. Corporate Governance, 5 (3), 467-479.

Aupperle, K.E., Carroll, A.B. \& Hatfield, J.D. (1985): An empirical examination of the relationship between corporate social responsibility and profitability. Academy of Management Journal, 28 (2), 446-463. 
Blyth, A. (2002): Investing in Africa, challenges and initiatives. Ethical Corporation, November, 26-30.

Business for Social Responsibility (2002): Overview of corporate social responsibility. http:www.bsr.org/BSRResources/ IssueBriefDetail.cfm?DocumentID=48809 (accessed 14 May 2004).

Business in the Community (2001). Investing in the future: City attitudes to environmental and social issues. http://www.bitc.org.uk/resources/research/research_publica tions/bie1.html (accessed 7 January 2004).

Business in the Community (2003). Responsibility driving innovation, inspiring employees. http://www.bitc.org.uk/ docs/FastForward2003_report_pdf.pdf (accessed 7 January 2004).

Carroll, A.B. (1979). A three-dimensional model of corporate performance. Academy of Management Review, 4 (4), 497-505.

Carroll, A.B. \& Buchholtz, A.K. (2000). Business \& society. Fourth edition, Cincinnati: South-Western College Publishing.

Chiang, H.T. \& Chia, F. (2005). An empirical study of corporate governance and corporate performance. Journal of American Academy of Business, 6 (1), 95-101.

Clarkson, M.B.E. (1995). A stakeholder framework for analyzing and evaluating corporate social performance. Academy of Management Review, 20 (1), 92-117.

De Jongh, D. (2004). A stakeholder perspective on managing social risk in South Africa: Responsibility or accountability? The Journal of Corporate Citizenship, Autumn (15), 27-31.

Donaldson, T. \& Preston, L.E. (1995). The stakeholder theory of the corporation: Concepts, evidence. The Academy of Management Review, 20 (1), 65-91.

Dowling, G.R. (2004). Corporate reputations: Should you compete on yours? California Management Review, 46 (3), 19-36.

Environics International (2002). Global CSR Monitor. http://www.globescan.com.

Ethical Corporation (2002). The business of business: Managing corporate social responsibility: what business leaders are saying and doing, 2002-2007. http:www.ethicalcorp.com (accessed 2 May 2003).

Ethical Corporation (2003). Analysis international standards for corporate responsibility. http://www.ethicalcorp.com (accessed 2 May 2003).

European Commission (2003). Getting returns on social responsibility. CSR Magazine, 2 (2,) 12-15.

Faruk, A. (2002). Corporate responsibility: Beyond niceness. The Ashridge Journal, Summer, 28-31.

Freeman, E.R. \& Liedtka, J. (1991). Corporate social responsibility: A critical approach. Business Horizons, 34 (4), July-August, 92-99.

Freeman, E.R. \& Reed, D.L. (1983). Stockholders and stakeholders: A new perspective on corporate governance. California Management Review, 25 (3), Spring, 88-106.

Forstater, M. (2002). What can corporate responsibility do in the fight against poverty in Africa? Ethical Corporation Magazine, November, 37-40.

Grayson, D. (2005). From responsibility to opportunity. Corporate Responsibility Management, 2 (2) 34-37.

Grayson, D., \& Hodges, A. (2001). Everybody's Business. First edition, London: Dorling Kindersley Limited.

Hall, J. \& Vredenburg, H. (2005). Managing stakeholder ambiguity. MIT Sloan Management Review, 47 (1), 11-13.

Hamann, R. (2003). Mining companies' role in sustainable development: The 'why' and the 'how' of corporate social responsibility from a business perspective. Development Southern Africa, 20 (2), 237-254.

Hamann, R. \& Acutt, N. (2003). How should civil society (and the government) respond to 'corporate social responsibility'? A critique of business motivations and the potential for partnerships. Development Southern Africa, 20 (2), 255-270.

Handy, C. (2002). What's a Business For? Harvard Business Review, 8 (12), 49-55.

Hart, S. L. (1997). Beyond greening: Strategies for a sustainable world. Harvard Business Review, January, 75 (1), 66-76.
Hart, S \& Milstein, M. B. (2000). Global sustainability and the creative destruction of industries. MIT Sloan Management Review, Fall, 41 (1), 23-33.

Hollender, J. (2004). What matters most: corporate values and social responsibility. California Management Review, 46 (4), 111-119.

Institute of Directors (2002). King Report on Corporate Governance for South Africa. Johannesburg: IOD.

Keeble, J. \& Turner, C. (2003). The business case for corporate responsibility. http://www.bitc.org.uk/docs/aurr_A4 The_Business_Case_2003.pdf (accessed 4 January 2004).

Kline, J.G., Smith, N.C. \& John, A. (2004). Why we boycott: Consumer motivations for boycott participation. Journal of Marketing, 68 (3), 92-109.

Linstone, H. \& Turoff, M. (1975). The Delphi method, techniques and applications. Massachussetts: Addison-Wesley Publishing Company.

Locke, R.M. (undated). Note on corporate citizenship in a global economy. http://mitsloan.mit.edu/50th/corpcitizenship.pdf (accessed 2 May 2003).

MacMillan \& Joshi (1997). Sustainable competitive advantage and firm performance: The role of intangible resources. Corporate Reputation Review, 1 (1), Summer/Fall, 81-86.

Mahon, J.F. \& McGowan, R.A. (1991). Searching for the common good: A process oriented approach. Business Horizons, 34 (4), July-August, 79-87.

Market \& Opinion Research International. (2002). Annual CSR Study. http://ww.mori.com/csr/annual (accessed 15 April 2004).

Martin, R.L. (2002). The virtue matrix: Calculating the return on corporate responsibility. Harvard Business Review, March, 511.

Matten, D. \& Crane, A. (2005). Corporate citizenship: Toward an extended theoretical conceptualisation. Academy of Management Review, 30 (1), 166-179.

McKinsey \& Company (2002). Investor opinion survey on corporate governance. London: McKinsey \& Company.

Mirvis, P. \& Googins, B. (2004). The best of the good. Harvard Business Review, December, 1-2.

Mintzberg, H, Simons, R, Basu, K (2002). Beyond selfishness. MIT Sloan Management Review, Fall, 44 (1), 67-74.

Moir, L. (2001). What do we mean by corporate social responsibility? Corporate Governance, 1 (2), 16-22.

Newell, R. \& Wilson, G. (2002) A premium for good governance. The McKinsey Quarterly, 3, http://www.ckinseyquarterly.com (accessed 8 April 2003).

Orlitsky, M. (2005). Payoffs to social and environmental performance. Journal of Investing. 14 (3), 48-52.

Paine, L., Deshpande, R, Margolis, J.D. \& Bettcher, K.E. (2005). Up to code: Does your company's conduct meet world-class standards? Harvard Business Review, December, 122-133.

Pearson, G. (2000). Making profits and sweet music. Business Ethics: A European Review, 9 (3), July, 191-199.

Petersen, R. (2005). Responding to changing stakeholder expectations. Marketing, June, S8.

Petkoki, D. \& Kersemaekers, S. (2003). The role of business in fighting HIV/AIDS. World Bank Institute Series on Corporate Responsibility, Accountability and Sustainable Competitiveness, 21 April - 9 May, http://www.worldbank. org/wbi/corpgov/csr/econferences/hivaids/pdf/hivaids_econ ference_report.pdf (accessed 6 March 2004).

Post, J.E. (2002). The 'Iron Law' of business responsibility revisited: Lessons from South Africa. Business Ethics Quarterly, 12 (2), 265-276.

Prahalad, C.K. \& Hart, S.L. (2002). The fortune at the bottom of the pyramid. Strategy \& Business, 26 (1), 55-67.

Roberts, S. \& Keeble, J. \& Brown, D. (2002). The business case for corporate citizenship. http:www.csrwire.com/pdf/BusinessCase-for-Corporate-Citizenship.pdf (accessed 10 May 2004).

Rowe, G. \& Wright. G. (1999). The Delphi technique as a forecasting tool: Issues and analysis. International Journal of Forecasting, 15, 353-375. 
Sarbanes-Oxley Act (2002). http//news.findlaw.com/hdocs/docs/ gwbush/sarbanesoxley072302.pdf (accessed 13 May 2003).

Sarre, R., Doig, M. \& Fiedler, B. (2001). Reducing the risk of corporate irresponsibility: The trend to corporate social responsibility. Accounting Forum, 25 (3), September, 300-317.

Senge, P. (1990). The fifth discipline: The art and practice of the learning organisation. London: Century Business.

Stemler, S. (2001). An overview of content analysis. Practical Assessment, Research \& Evaluation, 7 (17), http:PAREonline. net/getvn.asp?v=7\&n=172004 (accessed 17 February 2004).

Stigson, B. (2003). The business case for CSR. http://www.responsiblepractice.com/English/issues/wdcsdbusiness (accessed 11 April 2004).

Story, V., Hurdley, L., Smith, G. \& Saker, J. (2001). Methodological and practical implications of the Delphi technique in marketing decision-making: A re-assessment. The Marketing Review, 1, 487-504.

Straughan, A. (2003). Corporate social responsibility: an evolving view of the field. MHC International Monthly Feature, May, 1-5.

Swift, T. \& Zadek, S. (2002). Corporate responsibility and the competitive advantage of nations. http:www.accountability. org.uk (accessed 13 May 2003).

Tersine, R. J. \& Riggs, W. E. (1976). Models: Decision tools for management. Journal of Systems Management, October, 30-34.

Vermier, W., Van de Velde, E. \& Corten, F. (2005). Sustainable and responsible performance. Journal of Investing, 14 (3), 94-99.

Visser, W. (2005). Corporate citizenship in South Africa: A review of progress since democracy", The Journal of Corporate Citizenship, Summer (2005), 29-38.

Visser, W., Middleton, C. \& McIntosh, M. (2005). Introduction. The Journal of Corporate Citizenship, Summer (18), 18-20.
Visser, W. \& Sunter, C. (2002). Beyond reasonable greed. Why sustainable business is a much better ideal. Cape Town: Tafelberg, Human \& Rousseau.

Vogl, A.J. (2003): Does it pay to be good? Across the Board, Jan/Feb, 16-23.

Waddock, S.A., Bodwell, C. \& Graves, S.B. (2002). Responsibility: The new business imperative. Academy of Management Executive, 16 (2), 132-150.

Waddock, S. \& Smith, N. (2000). Corporate responsibility audits: Doing well by doing good. Sloan Management Review, Winter, 75-82.

Werther, W.B. \& Chandler,D. (2004). Strategic corporate social responsibility as global brand insurance. Business Horizons, 48, 317-324.

White, A.L. (2004). Lost in transition? The future of corporate social responsibility. The Journal of Corporate Citizenship, Winter (16), 19-24.

Williams, P.L. \& Webb, C. (1994). The Delphi technique: A methodological discussion. Journal of Advanced Nursing, 19, 180-186.

Wood, D. (1991). Corporate social performance revisited. Academy of Management Review, 16 (4), 691-718.

World Business Council for Sustainable Development (2000) CSR: making good business sense. http:www.wbcsd.ch/ DocRoot/5mbUksfWpqAgPpPpUq/Ue/csr2000.pdf (accessed 13 May 2003).

World Business Council for Sustainable Development. (2003). Sustainable development reporting, striking the balance. http:www.wbcsd.ch/DocRoot/GGFpsq8dGngT5K56sAW/200 30106_sdreport.pdf (accessed 13 May 2003).

Zadek, S. (2001). The Civil Corporation, the new economy of corporate citizenship. First edition. London: Earthscan Publications.

Zadek, S. (2002). The impact of public reporting. Ethical Corporation Magazine, October, 8-9.

Zadek, S. (2004). The path to corporate responsibility. Harvard Business Review, December, 1-8. 